\title{
Participation in Christ's body and his blood during celebration of Holy Communion as illuminated by the meaningful lenses of cognition and recognition
}

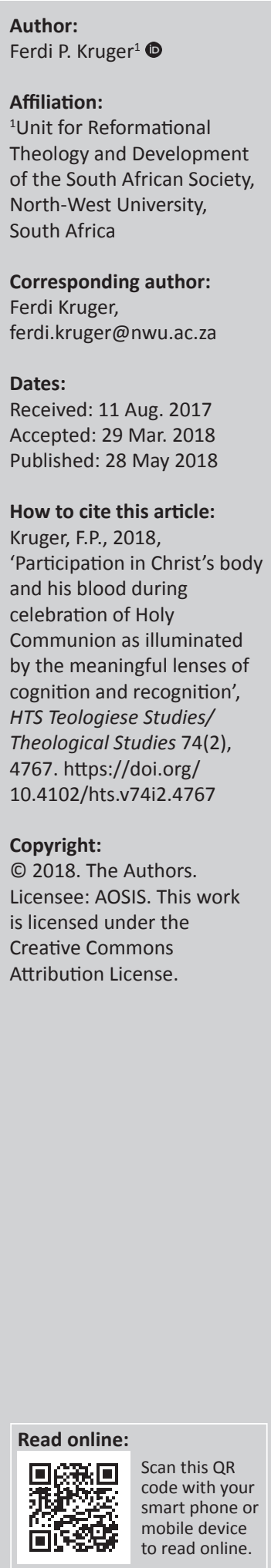

In this article, the author focusses on the importance and possible value of the concepts of cognition and recognition for reflection on what should actually happen during celebration of Holy Communion. The point of departure is that celebration, in essence, means that it should be a meaningful experience. The meaningfulness consists of the intriguing fact that participants are participating in Christ's body and in his blood while celebrating Holy Communion. In celebrating Holy Communion, people are engaging in a ritual that involves interaction with a variety of symbols. The author offers perspectives based on a qualitative empirical study in which people expressed their views on what they actually experience when celebrating the sacrament of Holy Communion. The article adheres to Browning's methodological insights. He describes research activity as ranging from description, to systemising (exploring practical wisdom and understanding), to strategising (practising strategic practical theology). The research problem is as follows: 'Could cognisance of the lenses of cognition and recognition of the deeper message of Holy Communion enrich the conscious appropriation of salvation while celebrating the sacrament of Holy Communion?' The research problem is addressed from the vantage point of understanding sacraments from a Reformed perspective. The concepts of cognition and recognition are highlighted in a brief historical description of what a sacrament is, taking into account the insights from social psychology regarding the essence of the concepts of cognition and recognition. The author further elaborates on the functioning of the concepts of cognition (phronesis) and recognition (anamnesis). In the last section of the article, the author utilises a hermeneutical interaction between descriptive and systemising perspectives to formulate strategies for how people's experiences of participation in Holy Communion can be enriched through the meaningful lenses of cognition and recognition.

\section{Introduction}

'When Christians gather to celebrate Holy Communion, they engage in ritual behavior that involves interaction with a variety of symbols' (Kubicki 2006:61). If liturgy is approached from this vantage point, we have to realise that liturgy in itself is an ensemble of signs or actions where the dominant value lies in the order of signification of meaning (Kubicki 2006:63). In particular, liturgy should support the central idea of Holy Communion, namely that a believer never receives Christ's gifts apart from receiving Christ himself (Horton 2009:400). Horton, in his intriguing discussion on Calvin's view on the Word and sacraments, indicates that it is pivotal that one should understand that as long as Christ remains outside of us, all that he has done for the salvation of his children is of no value to us (Horton 2009:398-400). There should be a sense of connection between the frequent celebrations of Holy Communion (action) and our realisation of its meaning (signification).

Wilson and Taylor (2015:15) relate to this view and indicate that signs and symbols enrich people's lives in that God uses what is common to prepare participants in liturgy for what has depth and meaning. Following on this, Forrester, Donald and Tellini (2004:70) reflect on the relationship between the sign and the signified and express the possibility that a distortion of sacraments could possibly manifest in people's minds. Their concern is that sacraments as visible signs of the invisible grace (mystery of Christ) are sometimes regarded as mere rites, rather than ongoing realities of assurance of participation in the body and in the blood of Christ (Forrester et al. 2004:71). Kubicki (2006:5) and Stetter (2013:381) raise a concern in this regard by referring to the gradual decline in the church's symbolic consciousness over the years. 
Two lenses emerge from literature, namely the lens of cognition (trying to make sense of) and the lens of recognition (remembrance). After all, during worship services and in liturgical acts, people try to make sense of their experiences and of their participation in liturgy (cf. Kruger 2016:8). Liturgy, in essence, is something that has to be experienced time and time again by each participant, and one possible key to unlocking meaningfulness is the lens of recognition (Ford 2005:300; Haarman 2004:279). Therefore, Immink (2014:40) argues that epiclesis and prayer should be regarded as pivotal in order to realise that participation in Holy Communion could be regarded as meaningful. Immink (2014:38) expands on the view that worshippers (participants) in fact experience the meaningfulness of their faith in liturgy by singing hymns, offering prayers, listening to the sermon and by celebrating the Holy Communion.

A memorable celebration of Holy Communion offers a permeating opportunity to scrutinise the fractured reality of life by remembering God's concern for the brokenness of life. The realisation of this remembrance is something that should be applied to people's lives. Liturgy as such invites people to look and to see that new perspectives on daily life are needed. For instance, the dynamic view that liturgy could offer possibilities for better discernment of ethical conduct in life is something that warrants further reflection. Liturgy in itself is probably one of the most meaningful acts in which Christians engage as part of their unique experience of faith because it relates to the substantive and meaningful aspects of faith. Within the context of this article faith in God implies that people can rely on him and depend on his reliability. Faith is at the centre of Christian life. Christians after all profess that they have been saved by faith and that they are aware that they now should live by faith in relationship with God. Meaningful participation in liturgy means that participants are involved in something of ultimate importance that greatly affects their daily lives. It is as if a mirror is held up in the sunlight, captivating people and drawing their attention. The mystical union with (the present) Christ is pervasively illuminated while celebrating Holy Communion (cf. Horton 2009:401; Lathrop 2015:307; McPartian 2008:219; Welker 2000:10-11).

The research problem is as follows: Could cognisance of the lenses of cognition and recognition of the deeper message of Holy Communion enrich the conscious appropriation of salvation while celebrating the sacrament of Holy Communion?

In order to address this research problem, the insights of Browning (1996:36) are regarded as suitable for this research, because of the emphasis on practices that are meaningful or theory-laden (Browning 1996:6). When faith communities are experiencing challenges in their practices, reflection on meaningful, theory-laden practices is needed, which includes reflection on the question of where are we now. Practical or sagely wisdom (phronesis) is needed. Browning (1996:13) describes the movement of research as a flow from description to systemising perspectives (exploring practical wisdom) to strategising perspectives (practising strategic practical theology).

\section{Descriptive perspectives}

The descriptive task is spurred by an acute awareness that a particular practice is problematic (Browning 1996:36). Applied to this study, the appropriation of salvation in celebrating Holy Communion is scrutinised in order to determine whether the lenses of cognition and recognition could enrich the meaningfulness of Holy Communion. The first movement in practical theological research entails the asking of intriguing questions regarding what we are doing and also what we should really be doing. This section now offers a brief description on the contours of the praxis from a South African perspective. The description is supported by the results of empirical work on people's cognition and recognition, which was undertaken in order to listen to people's narratives about their experiences of Holy Communion.

\section{A brief description of an emerging praxis within the South African context}

In the South African context, it seems as if the ideas of cognition (trying to understand) and recognition (remembrance) are subjacent to what people are experiencing in liturgy. Smit (2001:36), for example, is concerned about meetings (worship services) that really matter. He highlights people's unilateral understanding (cognition) of the essence of liturgy as those activities that reflect the role of the presiding minister among the gathered community of believers. Vos and Pieterse (1997:115) relate to this idea and underline the manifestation of an excessive appreciation of the cognitive aspects (mind and knowledge) and the neglect of emotion and sincere experiences within liturgy. People are sometimes exposed to the idea that the main act in worship services is to only listen to sermons. Niemandt (2007:10-12), on the other hand, underscores the challenge South African churches are facing, namely the influence of people who are longing for customs of long ago (lower-tier mentality), postmodern thinking, the reality of religion that has seemingly lost its power (post-Christianity) and the effects of globalisation. He describes the current challenge as the advent of a perfect storm. The spirit of the times is influenced by a definite dynamic that challenges customs and practices.

Tickle (2009:34; 2012:19) conducted extensive research on religion and its intimate connection with the existing culture. Liturgy as such should take into account what is happening in daily life. Tickle describes the characteristics of an emerging Christianity. Religion from the viewpoint of this author is a cable of meaning that keeps people connected to some purpose greater than themselves. From a historical view, it is important to realise the underlying dynamics of the emergence of Christianity. Emerging churches and the postmodern church movement have started to challenge the (merging) culture and a different view of thinking and 
learning (Kimball 2003:91). This emergent movement is interested in the role of multisensory experiences during worship services so that participating worshippers can learn through experience. The focus of the emergent movement is actually testing fundamental thinking in local churches and practical theological thinking within a South African context. Kimball (2004:81) indicates that multisensory worship involves seeing, hearing, tasting, smelling, touching and experiencing (Woodbridge 2008:197).

De Leede and Stark (2017:237) indicate that despite the functioning of a current multimedia culture with numerous opportunities for communication, oral communication still remains the most important manner of communication during worship services. The intriguing question is what people are visualising while they are listening. Are they hearing messages without direction to daily life? It seems that the commemoration focus of worship services in which God's deeds in the past are remembered in the present lies within the heart of a problematic praxis. It has to do with the realisation of liturgy that should enable participants to remember (retrieve) familiar things in the present moment (cf. Vorster 2011:65). Could it be true that celebration of Holy Communion also experiences the same kind of difficulty? The crossroads between faith and daily life seems to be constantly in the minds of people, and the relevance of what a community of believers are actually doing in celebrating Holy Communion seems to be at the core of interest.

The numbers in mainline churches are declining as people look for opportunities to participate in liturgy to experience meaningfulness. Scholars sometimes unilaterally criticise this tendency of people to look for other horizons and leave mainstream churches because they are not experiencing meaningfulness as a phenomenon of a consumer mentality, but within research on the power of rituals and symbols it seems that the idea of a meaningful remembrance is also evident. The literature study on people's experiences of Holy Communion indicated one possible shortcoming, namely that reflection on the shape of meaning (Sinngestalt) is sometimes realised without thorough reflection on the shape of celebration (Feiergestalt).

Wepener (2009:189) provides insight into the other side of the coin regarding people's experiences and articulates the fact that people increasingly long for the mystical side of liturgical experiences. Wepener (2017:150) describes the importance of rituals and symbolic consciousness in which a deeper relatedness is evident. The idea of a symbolised reality is the focal point in this kind of reflection. Wepener (2017:23) also highlights the fact that the manner in which people participate in rituals is influential in their own understanding thereof and also vice versa. People are increasingly becoming more interested in experiencing the symbolic aspects, rituals and symbols via their senses rather than in a mere cognitive manner. People want to communicate and to participate in invisible things within worship services. This provides the context within which people who are seeking deeper meaning in worship services and who want to experience the meaning of symbols and sacraments express their liturgical needs.

\section{Empirical perspectives \\ Data collection}

Browning (1996:94) indicated that the descriptive essence of research is to describe the research question in all of its situated richness, and therefore the empirical dimension on people's experiences regarding the celebration of Holy Communion could be further helpful in describing the underlying dynamics of the research question, namely: could cognisance of the lenses of cognition and recognition of the deeper message of Holy Communion enrich the conscious appropriation of salvation while celebrating the sacrament of Holy Communion?

Botma et al. (2016:182) indicate that a qualitative research approach sheds light on issues and data in the form of words related to a specific phenomenon. For this reason, feelings, behaviour and insights rather than numbers are important. The author selected respondents from two denominations in Potchefstroom, South Africa, who are acquainted with the essence of the celebration of the sacrament of Holy Communion within a Reformed tradition. Two groups from the congregations who meet as small groups for worship and Bible study were selected as samples. The author utilised the method of a descriptive-qualitative inquiry, a strategy that aims to provide a comprehensive summary of a phenomenon in everyday language (cf. Botma et al. 2016:194). This strategy was selected because the author intended to elicit a straight and honest description of participants' experiences with liturgy and sacraments to gauge their unique experiences while celebrating Holy Communion. Two focus (small) groups of at least 10 members each were selected. The purpose was to invite collective activity and discussion on how the participants feel about their own experiences (Botma et al. 2016:210). The facilitator (researcher) was interested in obtaining insight into the participants' understanding of celebrating Holy Communion and whether understanding and remembrance of the essence thereof was indeed evident. The facilitator (researcher) tried to listen to the participants and also tried to encourage participants to communicate amongst themselves (cf. Botma et al. 2016:210). Field notes of the responses were made and afterwards presented to the participants, who checked their correctness. The questions were raised in a semi-structured manner in which openended questions were asked and also stated in a conversational manner.

One group consisted of younger people between 30 and 40 years of age, while the other group consisted of people between 40 and 70 years of age. The main reason for the particular selection of persons above 30 years of age was that this age group experiences difficulty with sudden and rapid changes (Dingemans 1991:95). The cognition and recognition of people between 30 and 70 years of age regarding their 
experiences of Holy Communion could possibly contribute towards cognition and recognition being regarded as meaningful lenses. People between 30 and 70 years of age tend to cling to traditions. The author was interested in the views of this group of people. The interviewer raised each question during the interviews and provided the group with an opportunity to discuss the question in a reflective manner.

\section{Interview schedule}

The purpose of this research was to explore thoughts and feelings in a more descriptive manner and the questions offered a framework to work from. Therefore, this interview type could be regarded as a semi-structured interview (cf. Botma et al. 2016:206). The researcher was interested in the complexity or the issues evident in the respondents' understanding of the celebration of Holy Communion, but within the framework of cognition and recognition. The interview schedule (questions) was constructed on the basis of open-ended questions that were aimed at guiding rather than dictating the direction of the interview. The funnelling method was utilised, in which the questions were arranged along the lines of the interest in cognition and recognition. The first four questions addressed the interest in the role of cognition, while the other questions addressed the interest in the role of remembrance (recognition). The interview schedule contained the following questions that required the interviewees' opinions:

- What is the meaning of the sacrament of Holy Communion according to your understanding?

- Why do you think it is important to celebrate the sacrament of Holy Communion frequently?

- What do you think about while celebrating the sacrament of Holy Communion?

- Do you agree with the statement that people feel 'bored' or like passive onlookers while the sacrament of Holy Communion is being ministered, and what is your reason?

- Do you really think about the fact that you were saved by what Christ did as you celebrate Holy Communion?

- What conscious awareness of Christ's presence do you experience when celebrating the sacrament of Holy Communion?

- Do you think about specific realities in your life while celebrating sacraments? Be more specific.

- Why do you think that the celebration of the sacrament of Holy Communion is a good ritual or a dynamic, actual experience of salvation, in your understanding?

\section{Data analysis}

Analysis of Group 1 (people between 30 and 40 years of age): What is the meaning of the sacrament of Holy Communion according to your understanding? The group was unanimous that Holy Communion as a symbol of what Christ did for us should strengthen participants' faith lives:

- Why do you think it is important to celebrate the sacrament of Holy Communion frequently? The group responded that they hadn't really given much thought to this to date, mainly because they were used to the fact that it did not happen weekly in their congregation. After consideration, they felt that they should perhaps request a weekly practice from their congregation.

- What do you think about while celebrating the sacrament of Holy Communion? The group admitted that if they had to be honest, all aspects leading up to the actual celebration of Holy Communion were at times boring. Group members could think of times they were amazed by the meaning of Holy Communion and of salvation. They mentioned that the reading of communion formularies leading up to Holy Communion was sometimes overwhelming. They confessed that they knew that they should think about Christ's salvation, but the whole event was time-consuming. They also wondered about utilising technology more effectively.

- Do you agree with the statement that people feel 'bored' or like passive onlookers while the sacrament of Holy Communion is being ministered? Because of the duration of the Holy Communion celebration, some members of this group admitted to sometimes going to other worship services that did not last so long. They recognised that this attitude was not right and were ashamed to mention it. Group members felt that they didn't know how to communicate about this issue with the leaders in their church because they already felt guilty about sometimes being bored.

- Do you really think about the fact that you have been saved by what Christ did while celebrating Holy Communion? Group members shared that they felt guilty because they sometimes realised that the moment of celebration had gone by and they hadn't really thought about what Christ did for them. They knew about the wonderful message of Holy Communion, but they were having difficulties really appreciating this experience.

- What conscious awareness of Christ's presence do you experience while celebrating the sacrament of Holy Communion? The presence of Christ in Holy Communion is something that everyone should experience in their own hearts and is in fact a personal matter. The group revealed that they were not used to speaking openly about this. They did feel that they could discuss this in their small group and that they felt free to do that.

- Do you think about specific realities in your life while celebrating sacraments? The group asked the researcher to be more specific and added that they felt that they should be honest that they were not really experiencing this in Holy Communion.

Analysis of Group 2 (people between 40 and 70 years of age): What is the meaning of the sacrament of Holy Communion according to your understanding? Holy Communion is symbolic of the fact that Christ died on our behalf and that he gave us his Spirit. Believers take the bread and the wine, which are related to the body and the blood of Christ:

- Why do you think it is important to celebrate the sacrament of Holy Communion frequently? The group related that they grew up in the days when they only celebrated Holy 
Communion four times per year. The elders did their utmost to do house visits to ask about people's willingness to participate in Holy Communion. They got used to the elders inviting them to Holy Communion. They were glad that more frequent opportunities were becoming available to celebrate the Holy Communion, but the group felt that they were sometimes not really prepared to do so. They were afraid of eating the bread and drinking the cup of the Lord in an unworthy manner and therefore sinning against the body and blood of Christ.

- What do you think about while celebrating the sacrament of Holy Communion? The group members shared that they were amazed by the formula for distributing the bread and the wine. Some members said that the insight was sometimes lost by the time the bread and the wine reached them. In general, they experienced a solemn silence and thought about a devoted moment while celebrating Holy Communion.

- Do you agree with the statement that people feel 'bored' or like passive onlookers while the sacrament of Holy Communion is being ministered? The group shared that they realised the difficulty that their congregation was experiencing because of the number of people in the church. The group admitted that if they were honest, they felt like passive onlookers while the sacrament was being ministered, especially during the time after they had received the bread and the wine.

- Do you really think about the fact that you have been saved by what Christ did while celebrating Holy Communion? The group answered affirmatively but felt that they could definitely not say that they were thinking of it on a constant basis. They were anxious to receive the bread and the wine, but they realised that they should constantly think of what Christ did for us.

- What conscious awareness of Christ's presence do you experience when celebrating the sacrament of Holy Communion? The group said that this was something that we should reflect on more frequently. The acts of people, the words uttered by the liturgist and the signs sometimes become the main focus, rather than the meaning of Holy Communion. The group admitted that their attention span was limited.

- Do you think about specific realities in your life while celebrating sacraments? Group members shared that they did think about their lives, but they did not necessarily connect the meaning of Holy Communion with their daily lives. However, they were aware of the fact that it should be the case.

- Is the celebration of the sacrament of Holy Communion a good ritual or a dynamic, actual experience of salvation in your understanding? The group felt that it was a very important ritual, but they were wary of the concept of experience because of their religious backgrounds and the way they were educated.

\section{Interpretation of data}

The author indicated an interest in the meaningful lenses of cognition and recognition in people's experiences while celebrating Holy Communion. The researcher afterwards aimed at providing his own, independent cognition (understanding) of the responses and therefore the interpretation of data is offered in this section. Another reason for this is that the research question stated that this research was interested in the role of cognition and recognition in people's appropriation of salvation in celebrating Holy Communion. After completion of the interviews with both small groups, the following aspects emerged:

- Both small groups expressed the cognition that Holy Communion indeed has a deeper meaning. People are aware of the fact that it has to do with what Christ once did. It seems like the idea of what Christ once did is more prominent than the idea of what Christ did once and for all. The cognition of the believer participating in the body and in the blood of Christ while celebrating Holy Communion was not overtly communicated during the interviews. It seems that the participants thought about the meaning of Holy Communion more generically. This could be the result of a particular way in which they were edified.

- Frequent celebration of the Holy Communion and the idea of experiencing while celebrating seem like a cognitive dissonance. The participants were familiar with a specific liturgical tradition and were aware of the deeper meaning of Holy Communion. Practical issues seem to complicate the meaningful act of celebrating Holy Communion. It seems like people hold on to their past experiences from childhood and to what they are familiar with.

- It seems like both small groups were experiencing difficulties regarding what they should actually do while celebrating Holy Communion. People were aware of the meaning of Holy Communion but experienced difficulties with the activity (recognition) while celebrating Holy Communion. Circumstances and local practices within worship services could possibly endanger a meaningful celebration of Holy Communion. Utilisation of more senses seems to be something that people regard as important. Utilisation of only one of the senses could be responsible for distorted perceptions regarding the celebration of Holy Communion.

- It seems like the concept of recognition (remembrance) is often saved for something that happened in the past. The vivid remembrance of Christ who died, has risen and is also present in our midst is something that should be communicated and mediated more often.

- Both small groups indicated that the celebration of Holy Communion does not always enable them to link Christ's work in and through us with daily life. Therefore, the celebration of Holy Communion could possibly become a mere ritual. The concept of remembrance and its meaning is restricted to only the particular experience of Holy Communion at a certain date. The issue at stake here is that the continuation of liturgy and the continuation of the meaningful message of Holy Communion for daily life are endangered.

- It seems like an organic relationship between the concepts of cognition and recognition is preventing people from realising the meaning of Holy Communion for daily life. 


\section{Systemising perspectives}

During this movement in research the interest in normative practices and the question regarding what kind of normative practices should guide us are evident (Browning 1996:49). Insights from the Christian tradition could be incorporated within this reflection. This section offers perspectives from a Reformed viewpoint that could possibly enrich the understanding of people's experiences of Holy Communion as assurance of participation in the body and blood of Christ. Perspectives from Church History, Social Psychology and thoughts on the concepts of cognition and recognition could provide a framework for practical wisdom.

\section{Systemising perspectives from the reformation period and its relevance for the current liturgical praxis}

\section{Sacraments as visible words of God (multiple senses)}

Calvin, like Augustine, defined sacraments as visible words of God (Sproul 2002:7). Sacraments are outward signs through which God seals on our consciences the promises of his will to sustain the weakness of our faith, and we in turn attest our piety towards him in the presence of the Lord and before men (Sproul 2002:7). In short, it could be true to say that Calvin regarded a sacrament as a visible form of an invisible grace. God acts in the sacraments. He seals (attests, confirms) the promises he made to us in Jesus Christ. God really does this here and now. Here and now, God says, 'My promises are "for real"' (Wolterstorff 1992:292). Wolterstorff (1992:293) emphatically declares that participation in liturgy helps believers to be confronted by the acting God - or rather, by God acting.

Wilson and Taylor (2015:162-164) indicate that meals are a very important context for learning about God's abundant provision. Joyful eating and joyful drinking during the meal of Holy Communion should recognise God himself who is feeding his children and the fact that Jesus is the real bread of life (Wilson \& Taylor 2015:43). In eating the bread and drinking the wine, participants should recognise Jesus Christ as the signified reality. Eating the bread should signify the rejection of the power of sin, while drinking the wine should offer a view on the appropriation of the treasures from the treasury of Christ. Eating and drinking are filled with the idea of participation in the body and in the blood of Christ. The dynamic of movement and activity should become evident in the celebration of Holy Communion. In the section 'Analysis of Group 1' the participants indicated that they as participants in the celebration of Holy Communion experienced impediments because of inter alia the reading of communion formularies leading up to Holy Communion and regard it as overwhelming. They confessed that they knew that they should think about Christ's salvation while celebrating Holy Communion but that the whole event was time-consuming. The idea of appropriation is endangered by events that distort the meaningfulness of Holy Communion. It is a case of them knowing what is right but struggling to get it right.
The tension field between people's cognition (understanding) and their experiences is coming to the fore. On the opposite of this tension field the sacraments are, according to Calvin, instruments of the Holy Spirit (Rorem 2010:9). The power of the sacraments comes from the Holy Spirit. Horton (2009:400) elaborates on this idea and indicates that the union with Christ (in Christ) is central in the celebration of the Holy Communion. It is by the secret energy of the Spirit that we come to enjoy Christ and all his benefits, and therefore the Holy Spirit is the bond by which Christ effectively unites us to himself (Horton 2009:400). Immink (2011:77) expands on this topic and highlights the importance of epiclesis, namely the prayer that the Spirit should open and enlighten people's senses, hearts and minds. It is about a mystical union, mediated by the Spirit. Therefore, the sacraments are efficacious only for those who receive them with faith (Sproul 2002:10). When the Spirit works, he transmits those outward words and sacraments from our ears and our eyes to our soul (Sproul 2002:11). The Spirit is actually transmitting the power or significance of promises to people's lives. This section indicated that participants in the celebration of Holy Communion should be aware of the role of cognition within their participation in order that the importance of appropriation of the salvation could become central. Cognition, however, should not be regarded as mere cognitive functioning but should rather be regarded as interest in the acts of knowledge about, knowing how to be, knowing how to do and knowing how to live (Prétot 2015:5). Cognition is dealing with the cognitive dimension (thoughts), affective dimension (feelings) and also conative (doing) aspects of life (cf. Kruger 2016:8).

\section{Holy Communion as powerful remembrance}

Calvin was not interested in how Christ was or was not present in the bread and in the wine but rather directed his attention to the way in which Christ is present in action in the sacrament even though he is seemingly absent from the Earth in the flesh until his return (Welker 2000:87). The gift of the Holy Communion is nothing less than Christ himself, not merely his memory (Horton 2009:408). Calvin agreed with Luther in the sense that the assurance that lies in participation in Holy Communion has to do with the powerful remembrance of the mirifica commutation [marvelous exchange] (Horton 2009:408). In this sense of the word, it has to do with a real and vivid memory about the newness of life. The signs of the Holy Communion, namely bread and wine, are pledges of the real presence of Christ. They are the media through which Christ effects his presence (Sproul 2002:24). Calvin even described faith as the mouth and the soul of our stomach (Sproul 2002:32). The role of understanding (cognition) and remembrance (recognition) should not be underplayed in the reflection on the meaningfulness of the celebration of Holy Communion.

Different confessions of the 16th century echoed the importance of the lenses of cognition and recognition, for instance, the Belgic Confession and the Heidelberg Catechism. The Belgic Confession, Article 35, makes it clear that the 
essence of the sacrament of the Holy Communion has to be clear. According to the Belgic Confession, it is certain that Christ did not prescribe his sacraments for us in vain, because he works in us all he represents by means of these holy signs, although the manner in which he does it goes beyond our understanding and is incomprehensible to us, just as the operation of God's Spirit is hidden and incomprehensible. The element of engagement is further evident from this confession, namely an engagement of being together with thanksgiving and in a holy remembrance of the death of Christ, our Saviour.

The Heidelberg Catechism, Lord's Days 28-30, Question 76, like the Belgic Confession, is interested in what it means to eat the crucified body of Christ and to drink his spilled blood. In the answer to this question the issue is raised that it means more than one could see with the naked eye. Through the Holy Spirit, who lives both in Christ and in us, we are united more and more with Christ's blessed body. And so, although he is in heaven and we are on Earth, we are flesh of his flesh and bone of his bone. We forever live on and are governed by one Spirit, as members of our body are by one soul. It is evident that the concepts of meaning (cognition) and remembrance (recognition) are evident in this context. The assurance of the Holy Communion is that Christ wants to assure us, by this visible sign and pledge, that through the Holy Spirit's work, we share in his true body and blood as surely as our mouths receive these holy signs in his remembrance.

\section{Systemising perspectives from the viewpoint of social psychology}

\section{Perspectives on cognition}

The concept of cognition (as a lens) could be significant in reflecting on the meaningfulness of the celebration of Holy Communion. A lens clarifies and does not dictate (Peterson 2003:21). Applied to the topic of this conference, it should be recognised that something has gone terribly wrong in people's cognition on sacraments. It could be that people are present when the sacraments are celebrated but are bored because the deeper meaning of salvation has been missed and it has become a matter of 'once upon a time an important and even impersonal event happened'.

Fiske (2004:123) indicates that cognition constitutes the process through which people think about and make sense of other people, themselves and of their social situations. People's memories store everything they know. People's emotional experiences are influenced not only by their concrete situation but also by their cognitive observation, appraisal or interpretation of that particular situation (sacrament) (Eysenck \& Keane 2010:571-572). Therefore, Mitchell (2008:19) underscores the fact that every human experience is always in interaction with a specific person, place or thing. Human experiences are recalled by memory as images or pictures. The mind senses what is happening through our eyes, ears, noses, tongues and touch. The cognition regarding a strange kind of presence, the presence of someone who has died, who is present and yet also awaited and expected, is something that should be clear (Welker 2000:5). Is it possible that people could argue like the philosopher, Immanuel Kant, in describing Holy Communion as a 'sad colloquy'? What kind of cognition is established when little of Jesus' table fellowship is evident when the sacraments are celebrated? Could it be true that the celebration of sacraments can be over even before it has really begun?

\section{Perspectives on recognition}

Eysenck and Keane (2010:260) define 'recognition' as an action of memory, which includes remembrance and familiarity. In the process of recognition (remembrance), people recall information based on their contextual framework while the process of familiarity (notoriety) has to do with the recognition of things that are perceived. Wood and Wood (1999:199) are adamant that recognition is not the same as a mere recalling of facts. People remember things because they are familiar with events or facts and because of previous experiences. Atkins (2004:13) draws a more concrete picture of recognition (remembrance). He is adamant that recognition is the process through which people create a living reality on the basis of memories of the past.

It is furthermore interesting that people are able to remember things more easily once they have named them in words and in formulation (Atkins 2004:21). Words are like the bar codes at the back of products that are being purchased. Words have a trigger impact on people's memories because they recall memories. When a person remembers someone familiar to them, the brain makes a connection with a set of data (cognition) and a set of emotions (joy, sadness) that that person stirred up and still stirs up. Therefore, our remembrance functions as a re-embodiment, a bringing together or bringing alive of that which is past and making it effective in the present and for the future (Atkins 2004:54). Feelings for persons remembered therefore connect with data about the person (cognition) and in turn connect with current feelings about the particular relationship. In this sense we could also speak of connected memories.

People remember things that they have lived through and thought through. The sacrament of Holy Communion as a meaningful act is something that should indeed be thought through; otherwise it could become a mere rite. Remembrance acts like a dynamic propellant that time and again offers a discovery of the meaning of Holy Communion. According to Venter, Symington and Van Wyk (2007:275), Augustine described the information in one's memory as the 'stomach of the soul'. In the stomach, sweet and also bitter memories are evident. Augustine was clear about the fact that remembrance has to do with the recognition of God himself. According to this view of Augustine, recognition of God is important for people to realise the deeper essence of life. Therefore, the expectation of things to come and the remembrance of things in the past function as contagious inspiration for the here and now (Venter et al. 2007:360). Recognition is therefore a process that integrates memories 
into a meaningful framework during participants' celebration of sacraments.

\section{Systemising perspectives on the essence of sacraments, cognition and recognition}

Understanding the essence of sacraments - Mystery or sacramentum?: The early church allocated the concept of sacramentum to the biblical concept of mysterion (Browning \& Reed 1985:28). In fact, when the apostle Paul uses this concept, it denotes something that has not yet appeared and things that still exist in the counsel of God and have not yet been realised in history as fulfilment of that counsel (Ridderbos 1985:47). Ridderbos therefore brings the concept of mystery in connection with the eschatological promise of redemption in the time appointed for it (Ridderbos 1985:47). According to Bromiley (1985:617), it is worth noting that the concept of $\mu v \sigma \tau$ prov is connected to the word of the cross but in a rather comprehensive and extensive manner. Therefore the eschatological tension between 'yet' and 'not yet' is simultaneously evident. The mystery of the message of the cross has already been fulfilled in the cross of the Lord, and the heavenly reality breaks into this world so that two dispensations meet each other. Within this mystery there is the expectation of what should happen with the second coming of Christ.

Browning and Reed (1985:29) indicate that the concept of $\mu v \sigma \tau$ ṕrov has been used in the gospels within the particular context of the Kingdom of God. In the gospels, the concept of mystery functions in close proximity to the dynamic presence in Christ. Therefore, the mystery of God is Jesus Christ himself (Browning \& Reed 1985:28). Sharing or celebrating a sacrament entails sharing his special presence, the King of the Kingdom. The sacramental sign is the sign of Christ's presence and his presence is the abiding reality (Browning \& Reed 1985:28). God's mystery is not abstract but entails a relationship within a human community. God's family, the believers, are sharers in the divine mystery, which is Jesus Christ and our fellowship with him (Browning \& Reed 1985:29). A sacrament therefore has to do with relatedness. It is not about a thing or object; it is rather personal. God's mystery, his saving grace, has been hidden, but it was never absent. It is revealed in Christ. Therefore, celebration of the sacrament of Holy Communion should have an effect and it offers opportunities to proclaim God's grace and his presence until he comes. Our view of the sacraments will become biased if the idea of the mystery is not an intrinsic part of our reflection. Horton (2009:408) elaborates on this idea of what is recognised. He indicates that a participant's memory (recognition) of the sacraments is not just a memory of Christ or even of his benefits but rather of Christ himself.

\section{Perspectives on $\phi \rho 0 v \eta \sigma i ́ \varsigma$ [cognition] and $\alpha v \alpha \mu v \eta \sigma \iota \varsigma$ [remembrance]}

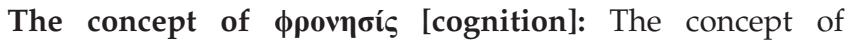
$\phi \rho o v \eta \sigma i c$ is possibly the closest to an understanding of what cognition entails. Louw and Nida (1989:259) indicate that

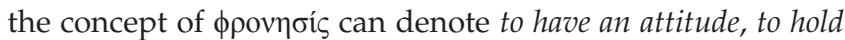

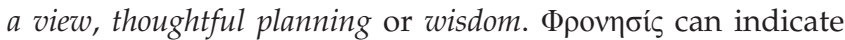

the psychological faculty of thoughtful planning, often with the implication of being wise and provident in a way of

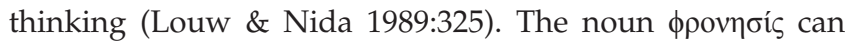
also denote the idea of an understanding that results from insight (Louw \& Nida 1989:384). The wisdom or discernment evident in the concept of phronesis as practical wisdom is therefore the driving force behind the actions of religious communities (Louw 2015:62). Cognition (phronesis) is not mere cognitive knowledge regarding content but rather insight and knowledge that are thoroughly experienced. Celebration of Holy Communion without discernment and understanding of the meaning thereof for daily life could possibly lead towards mere cold formalism without a sense of meaningfulness regarding realities in life. Cognition (phronesis) opens windows towards the organic functioning of lex orandi, lex credendi [the order of supplication determines the rule of faith] (cf. Wepener 2017:23).

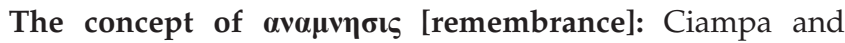
Rosner (2010:542) indicate that the essence of a worship service lies in the idea of remembrance. McShane (1999:132) in turn underscores the fact that the concept of $\alpha v \alpha \mu v \eta \sigma r \varsigma$ is used in I Corinthians 11 within a framework in which the idea of $\sigma u v \varepsilon \rho \chi \varepsilon \sigma \theta \alpha \mathrm{r}$ [meeting] is prominent. Therefore, Pakpahan (2012:115) is convinced that remembrance should be understood as closely linked to a meeting with God. The activity of $\alpha v \alpha \mu v \eta \sigma 1 s$ is the action through which the past becomes new and creative in the present (Pakpahan 2012:118). It could also be described as the action through which importance (meaning) is allocated to particular things with which people are familiar. Haarman (2004:276) in turn mentions the idea that the act of remembrance has to lead towards the fact that the reality of Christ's presence should become reality through the work of the Holy Spirit.

Within the framework of the concept of $\alpha v \alpha \mu \nu \eta \sigma 1 s$, it is important to recognise the fact that remembrance is more than a mere remembrance of the cross; it should be a remembrance of its meaning (Jordaan 1990:55). It is clear that $\alpha v \alpha \mu v \eta \sigma 1 \varsigma$ should not be confused with a sad idea of death and a funeral (Lammens 1968:139). It is not about a remembrance of in memoriam but rather a remembrance of the decisive act of victory in Christ. It is about the remembrance of the cross and death of Christ but within the light of his resurrection. Immink (2014:226) highlights the fact that the emphasis is not primarily on the crucified Christ but on the risen Lord, who allows us to experience his redemptive presence. Therefore, the remembrance has the character of eucharistie, an act of praise and of thankfulness (Van Beelen 1996:98).

Long (2009:21) indicates that people are not hungry for more worship services per se but for more experiences of God. They are hungry to experience the mystery. Sproul (2002:232) and Willigen (2015:93) indicate that remembrance $(\alpha v \alpha \mu v \eta \sigma 1 \varsigma)$ should not be confused with a mere subjective mental recollection of facts. Remembrance entails someone assigning an active role to someone they remember or even becoming engaged in things that they are remembering 
(Sproul 2002:232). No one can only look back at the past without looking forward to the consummation. Based on what is remembered and currently celebrated, there is also something of a forward-looking anticipation of the wedding feast of the Lamb (Rorem 2010:13; Sproul 2002:233). It is clear that people's minds are more satisfied when they are able to allocate a name to a certain experience, especially if that experience involves an element of mystery (cf. Atkins 2004:99). The mind (cognition) associates the feelings of the holy with the mystery and also with the object to which it is attached (Atkins 2004:99). The central act of remembrance spans dimensions of time and is influential in providing people an idea of the meaningfulness of life.

\section{Strategising perspectives}

Browning refers to this movement of strategising perspectives as theological reasoning (Browning 1996:56). The researcher should become aware in this movement of what course of action the situation requires. Right at the start two lenses were identified in reflecting on a meaningful experience of celebration of participation in the body and blood of Christ in Holy Communion, namely cognition and recognition. The two concepts are outstretched arms towards meaningfulness. Both lenses influence the manner in which participants experience the sacramental essence of Holy Communion. The research started according to the insights of Browning with a crisis in praxis, but now during this movement it is about a reflection on a critical praxis (Browning 1996:55-56).

\section{Lens 1: Cognition influences the celebration of the Holy Communion}

The literature review and the empirical study highlighted the fact that people long for meaningful experiences within the liturgy. This also manifested in the empirical research, where participants indicated that they were aware of the meaning of Holy Communion on the one hand, but didn't always experience its meaning on the other hand because of practical circumstances. Respondents also indicated that they were trying to make sense of events and of the liturgy. Browning and Reed (1985:63) highlight that the sacraments perform or accomplish something in people's minds and lives. In this sense, it is important to realise that meals and celebrations are indeed meaningful within any society and especially within the church as a community of believers. Knowing what people eat, who eats it, why people eat it and how they do it tells an observer much more about a particular community. Meals are far more than the mere gaining of enough food to get through the day (Lathrop 2015:185). Within the meal of Holy Communion, the essence is about spiritual saturation (Wepener 2010:150). The expression 'you are what you eat and how you eat' is relevant in more than one sense within the context of celebration of Holy Communion. The celebration of Holy Communion is a means of sealing the grace of the promises that are preached, to make the doubting human heart more sure of the truth of God's acceptance in Christ (Wepener 2010:128).
Müller (1990:76) makes it clear that the sacrament of Holy Communion is not a mere sign (signa nuda) but rather a guarantee of God's promises. It is about God's inclusion of his children within the sphere of his love and therefore believers should realise that their understanding of celebration is something that includes both the cognitive aspect and the affective component (the experience). Utilisation of all senses is needed for cognition of what happens during celebration to appropriate the meaning of the sacrament. After completion of the empirical work conducted, it became evident that people from a Reformed tradition should strive towards cultivating an ever-bigger awareness of the importance of a total involvement (commitment) while celebrating Holy Communion (cf. Müller 1990:77).

The cultivating activity should result in a more intimate bond between God and his children and between participants during celebration. This closer bond has to point towards what should be different and what should be changed in daily life. The concept of mysterion that was discussed in this article could enrich cognisance of the fact that celebration of Holy Communion in essence focuses on the celebration of the secret of Holy Communion, namely Jesus Christ. This understanding is not a blind alley but rather a window that provides vision on life. The concept of sacramentality certainly provides a foothold for cognition because of the profound awareness that an invisible divine presence is disclosed through visible realities (Kubicki 2006:16). The reason for this is that sacramentality also has to do with a certain way of viewing and understanding reality. The deeper meaning of liturgical acts and of celebration of the Holy Communion is indeed something that should receive continuous attention.

Liturgists have to consider the ministry of the sacrament of Holy Communion as important. Careful liturgical planning seems to be paramount. Why? Despite previous experiences and an understanding of Holy Communion, liturgists should help people understand the meaning and the meaningful experience of participating in the body and in the blood of Christ during the celebration of Holy Communion. Symbolically important meals are after all pivotal in people's experiences of their own faith, because meaning is determined through participation in the meal. Within the celebration of Holy Communion, one should note the fact that Christian churches are meal-keeping assemblies that remember the meal-keeping of Jesus and believe that they encounter the risen and present Christ in the meal of Holy Communion (cf. Lathrop 1999:188). Cognition and celebration are interrelated. Cognition provides content and purpose to celebration, and celebration in turn contributes towards a colourful experience of meaning. Cognition provides the deeper motivation for celebration and enhances participation in celebration.

\section{Lens 2: Recognition influences the vividness of celebration}

The empirical work revealed that people experience difficulty with the fleeting moments of remembrance instead 
of continuous remembrance of the meaning of Holy Communion. Remembrance should create opportunities to experience anew the reality of Christ (White 1999:104). The power of recognition (anamnesis) lies in reliving the saving acts of God in such a powerful manner that it enables us to appropriate all God's promises. Remembrance viewed from a liturgical angle has to do with the memory of familiar aspects or persons that form the foundation for living memories and vivid experiences (Welker 2000:126). Remembrance therefore draws people into the reality of the fullness of the life in Christ. Moltmann (2008) indicates the importance of this kind of remembrance in saying:

without the memory of Christ's passion there is no Christian meditation on the future life and conversely, without hope for the coming of Christ and therefore the remembrance of Christ loses its power. (p. 103)

Remembrance as symbolised in the Holy Communion is a prominent building block of people's expectation of the here and now and the future. Remembrance stimulates hope against any kind of hope.

Vorster (2011:64) also highlights that remembrance is not a passive activity of bringing in remembrance but rather of being confronted by the living and present Christ. It is also important to realise that remembrance during celebration of Holy Communion is much more than a mental or intellectual remembrance of a past event. Welker (2000:126) mentions the idea of remembrance as an act or even a re-enactment of Christ's triumphant sacrifice and the grace to make its benefits available to believers in the present. In a certain sense, it could also be said that the lens of recognition opens the window of a revitalised and concentrated experience of Holy Communion that expands the past, present and future. Remembrance enables participants in liturgy to link memory with significance (Atkins 2004:63). It functions like a photograph. In seeing the photograph, it is not only the person but also what the person did that comes to the fore. Through bread and wine our memories are able to relate to Christ and to what he has done (Atkins 2004:63).

Remembrance should lead towards a sharpened vision of life. God's concern about human dignity, for example, and his willingness to reconcile his children should enable a remembering community of believers to have discernment when it comes to phenomena like racism, xenophobia, immorality and social injustice. Remembrance (recognition) has to lead towards comprehension of God's dominion in society but also to a renewed responsibility towards society (cf. Vorster 2011:65). People have to think about the reality of life while celebrating Holy Communion. To participate in Christ's body and blood implies a participation in the richness of this promise within the concreteness of a liturgy of life.

In this way, celebration of the Holy Communion could become a re-experience of the incorporation in Christ and enable people to become what they receive by means of bread and wine. Recognition is at the core of what should be happening while celebrating Holy Communion.
Recognition is the umbilical cord with the past, the anchor in the present and the window on the future. In fact, in every worship service, participants in liturgy should remember the good message regarding Christ's death and his resurrection (Smit 2008:310). Remembrance in this instance of the celebration of Holy Communion has to do with more than mere memory. It is indicated that the functioning of the lenses of cognition and recognition on the deeper message of Holy Communion are enriching the conscious appropriation of salvation while celebrating the sacrament of Holy Communion. Recognition (remembrance) could be regarded as the spark that is needed in order for participants in Holy Communion to experience the meaningfulness of celebration.

\section{Conclusion}

The article started by asking whether cognisance of the lenses of cognition and recognition of the deeper message of Holy Communion could enrich the conscious appropriation of salvation while celebrating the sacrament of Holy Communion. This article responded positively to the research question and a framework of four quadrants emerged, namely participation, cognition, recognition and celebration. In order to address this issue, interviews were held. People acknowledged that they understood the essence of Holy Communion but often struggled to remember it while celebrating Holy Communion. It also became evident that cognition and recognition should be considered as bifocal lenses. The view on celebration is stretched further towards participation, while celebration is aimed at participation in daily life. The essence of what is happening within the one quadrant inevitably leads towards change in the other quadrants. Participation in the body and in the blood of Christ in Holy Communion without thorough cognition and the vividness of recognition could seriously endanger a festive celebration of Holy Communion and also the appropriation of salvation. The celebration of Holy Communion without the cognition of the meaningfulness of true participation could lead to formalism. The celebration of Holy Communion without recognition (remembrance) could lead to a ritual of mere thinking of what happened thousands of years ago and blind spots about the continuation of liturgy could occur.

\section{Acknowledgements Competing interests}

The author declares that he has no financial or personal relationships which may have inappropriately influenced him in writing this article.

\section{References}

Atkins, P., 2004, Memory and liturgy. The place of memory in the composition and practice of liturgy, Ashgate, London.

Botma, Y., Greeff, M., Mulaudzi, F.M. \& Wright, S.C.D., 2016, Research in health sciences, Pearson, Cape Town.

Bromiley, G.W., 1985, 'Phronesis', in Theological dictionary of the New Testament pp. 1275-1278, Eerdmans, Grand Rapids.

Browning, D.S., 1996, A fundamental practical theology, Fortress Press, Minneapolis, MN. 
Browning, R.L. \& Reed, R., 1985, The sacraments in religious education and liturgy, Religious Education Press, Birmingham.

Ciampa, R.E. \& Rosner, B.S., 2010, 'The first letter to the Corinthians', in The pillar New Testament Commentary, Eerdmans, Grand Rapids.

De Leede, B. \& Stark, C., 2017, Ontvouwen. Protestantse predking in de praktijk Boekencentrum, Zoetermeer.

Dingemans, J.J.C., 1991, Als hoorder onder de hoorders, J.H. Kok, Kampen.

Eysenck, M.W. \& Keane, M.T., 2010, Cognitive psychology, Psychology Press, New York.

Fiske, S.T., 2004, Social beings: A core motives approach to social psychology, Wiley, Princeton, NJ.

Ford, D.F., 2005, The modern theologian. An introduction to Christian Theology since 1919, Blackwell, Oxford.

Forrester, D.B., Donald, J.J.H. \& Tellini, G., 2004, Encounter with God: An introduction to Christians worship and practice, T\&T Clark, London.

Haarman, M., 2004, Dies tut zu meinem gedenken, Neukircher Verlag, Kempton.

Horton, M.S., 2009, 'Union and communion: Calvin's theology of Word and sacrament', International Journal of Systematic Theology 11(4), 399-414. https:// doi.org/10.1111/j.1468-2400.2009.00468.x

Immink, F.G., 2011, Het heilige gebeurt, Boekencentrum, Zoetermeer

Immink, F.G., 2014, The touch of the sacred. The practice, theology and tradition of Christian worship, Eerdmans, Grand Rapids, MI.

Jordaan, G.J.C., 1990, 'Gedagtenis, verkondiging en gemeenskap as aspekte van die nagmaal', Koers 55(1), 51-66.

Kimball, D., 2003, The emerging church: Vintage Christianity for new generations, Zondervan, Grand Rapids, MI.

Kimball, D., 2004, Emerging worship: Creating worship gatherings for new generations, Zondervan, Grand Rapids, MI.

Kruger, F.P., 2016, 'Attitude change through understanding (cognition) of the influence of the persuasive language of liturgy', HTS Teologiese Studies 72(2), 1-10. https:// doi.org/10.4102/hts.v72i2.3234

Kubicki, J.M., 2006, The presence of Christ in the gathered assembly, Continuum, London.

Lammens, G.N., 1968, Tot zijn gedachtenis. Het commemoratiewe aspect van die avondmaalsviering, J.H. Kok, Kampen.

Lathrop, G.W., 2015, 'Saving images: New Testament metaphors and the purpose of Christian worship', Studia Liturgica 89(4), 290-308.

Long, T.G., 2009, The witness of preaching, Westminster John Knox, Louisville, KY

Louw, D.J., 2015, Academic theology: Between sapientia (wisdom) and scientia (science). Theory formation in practical theology, University of Stellenbosch, Stellenbosch.

Louw, J.P. \& Nida, E.A., 1989, Greek English lexicon of the New Testament (I), United Bible Studies, New York.

McPartian, P., 2008, 'Catholic perspectives on sacramentality', Societas Liturgica 38(2), 219-241.

McShane, A., 1999, I and II Corinthians, Bath Press, Glasgow. (What the Bible teaches: Richie New Testament Commentaries).

Mitchell, H.H., 2008, Celebration and experience in preaching, Abingdon Press, Nashville, TN.
Moltmann, J., 2008, A broad place: An autobiography, Fortress, Minneapolis, MN.

Müller, J., 1990, Die erediens as fees, N.G. Kerkboekhandel, Pretoria.

Niemandt, N., 2007, Nuwe drome vir nuwe werklikhede, Lux Verbi, Wellington.

Pakpahan, B.J., 2012, God remembers. Towards a theology of remembrance as a basis of reconciliation in communal conflict, VU University Press, Amsterdam.

Peterson, G.R., 2003, Minding God: Theology and the cognitive sciences, Fortress, Minneapolis, MN.

Prétot, P., 2015, 'Benchmarks for a history of liturgical formation', paper presented at the Societas Liturgica, Quebec, Canada, 11th August.

Ridderbos, H., 1985, Paul. An outline of his theology, J.H. Kok, Kampen.

Rorem, P., 2010, Calvin and Bullinger on the Lord's Supper, Gorgia Press, Chicago, IL.

Smit, A., 2001, Meetings that matter, Lux Verbi, Wellington.

Smit, D.J., 2008, Geloof en openbare lewe, Sun Press, Stellenbosch.

Sproul, R.C., 2002, Reclaiming Calvin's doctrine of the Lord's Supper, P\&R Publishing, London.

Stetter, M., 2013, 'Viva Vox Evangelii-reforming preaching', in J. Hermelink \& A. Deeg (eds.), The transformative dimension of preaching, pp. 376-387, Evangelische Verlaganstalt, Leipzig.

Tickle, P., 2009, The great emergence: How Christianity is changing and why, Eerdmans, Grand Rapids, MI.

Tickle, P., 2012, Emergence Christianity: What it is, where it is going, and why it matters, Baker Books, Grand Rapids, MI.

Van Beelen, J., 1996, Doet dit tot Mijn gedachtenis, J.J. Groen en Zoon, Leiden.

Venter, P., Symington, J. \& Van Wyk, A., 2007, Augustinus se belydenisse, Lux Verbi, Wellington.

Vorster, J.M., 2011, Menswaardigheid, versoening en vergiffenis, V\&R Drukkers, Pretoria.

Vos, C.J.A. \& Pieterse, H.J.C., 1997, Hoe lieflik is u woning, RGN, Pretoria.

Welker, M., 2000, What happens in communion? Michigan, Grand Rapids, MI.

Wepener, C., 2009, 'Ontdek eietydse tendense en uitdagings rondom die erediens', in C. Wepener \& J. Van der Merwe (eds.), Ontdekkings in die erediens, pp. 181-194, Lux Verbi, Wellington.

Wepener, C., 2010, Aan tafel met Jesus, Bybel Media, Wellington.

Wepener, C., 2017, Die reis gaan inwaarts, Sun Media, Stellenbosch.

White, J.F., 1999, The sacraments in Protestant practice and faith, Abingdon Press, Nashville, TN.

Willigen, M.A., 2015, Christus volgen. Doop en avondmaal in de vroege kerk, Roayal Jongbloed, Heerenveen.

Wilson, N. \& Taylor, N.R., 2015, Bible signs and symbols, Baker Books, MI.

Wolterstorff, N., 1992, 'The reformed liturgy', in D.J. McKim (ed.), Major themes in the reformed tradition, pp. 273-303, Eerdmans, Grand Rapids, MI.

Wood, S.E. \& Wood, E.G., 1999, The world of psychology, Alyn \& Bacon, London.

Woodbridge, N.D., 2008, 'Evaluating the changing face of worship in the emerging church in terms of the ECLECTIC Model: Revival or a return to ancient traditions?', Practical Theology in South Africa 23(2), 336-355. 